\title{
Model Implementasi Kebijakan Publik dalam Pengelolaan Sampah dan Kebersihan Kota Palembang
}

\author{
HARDIYANSYAH ${ }^{1}$, RAHMAD EFFENDI $^{2}$ \\ ${ }^{1}$ Fakultas Ilmu Komunikasi, Universitas Bina Darma, Jl. Ahmad Yani No. 12 Palembang \\ ${ }^{2}$ Fakultas Ekonomi, Universitas Bina Darma, Jl. Ahmad Yani No. 12 Palembang \\ 1email: hardiyansyah@mail.binadarma.ac.id, 2 rahmad_effendi@mail.binadarma.ac.id.
}

\begin{abstract}
The purpose of this study is to examine and discuss a model of public policy implementation in Waste Management and Health in Palembang. This research uses descriptive qualitative research methods with techniques of data collection through observation, documentation studies and in-depth interviews to selected informants. The conclusion that can be drawn are as follows: (1) a model of policy implementation in hygiene and waste management in the city of Palembang lead to models of policy implementation Edwards III which includes factors of communication, executive attitudes, resources, and bureaucratic structures; (2) reality show that communication factor, executor attitude, resources, and bureaucratic structure proposed by Edwards III needs to be coupled with other factors, namely "leadership commitment." In the study it was found that the commitment of the leadership (mayor) apparently helped complete four factors ; (3) models of policy implementation Edwards III consists of four factors, as reconstructed into five factors, namely: communication, executive attitudes, resources, bureaucratic structures, and leadership commitment.
\end{abstract}

Keywords: policy implementation, garbage, cleanliness.

\begin{abstract}
Abstrak. Tujuan penelitian ini adalah untuk mengkaji dan membahas model implementasi kebijakan publik dalam Pengelolaan Persampahan dan Kebersihan di Kota Palembang. Penelitian ini menggunakan metode penelitian kualitatif deskriptif dengan teknik pengumpulan data melalui observasi, studi dokumentasi dan wawancara mendalam kepada informan terpilih. Kesimpulan yang dapat diambil adalah sebagai berikut: (1) model implementasi kebijakan dalam pengelolaan kebersihan dan persampahan di Kota Palembang lebih mengarah kepada model implementasi kebijakan dari Edwards III yang meliputi faktor komunikasi, sikap pelaksana, sumber daya, dan struktur birokrasi; (2) realitas menunjukkan bahwa faktor komunikasi, sikap pelaksana, sumber daya, dan struktur birokrasi yang dikemukakan oleh Edwards III perlu ditambah dengan faktor lain, yaitu "komitmen pimpinan." Dalam penelitian ditemukan bahwa komitmen pimpinan (walikota) ternyata turut melengkapi keempat faktor tersebut; (3) model implementasi kebijakan dari Edwards III yang terdiri dari empat faktor tersebut, setelah direkonstruksi ulang menjadi lima faktor, yaitu: komunikasi, sikap pelaksana, sumber daya, struktur birokrasi, dan komitmen pimpinan.
\end{abstract}

Kata kunci: implementasi kebijakan, persampahan, kebersihan.

\section{Pendahuluan}

Tahun 2006, Palembang merupakan kota terkotor dan terjorok. Predikat tersebut wajar diberikan kepada Kota Palembang karena saat itu sampah berserakan di mana-mana, terutama di kawasan perbelanjaan tradisional, terminal, bantaran sungai Musi, dan di sepanjang jalan protokol. Namun, seiring dengan berjalannya waktu dan pelaksanaan otonomi daerah, pemerintah kota dan masyarakatnya berusaha sedemikian rupa menata kota Palembang sehingga status kota kotor dan jorok berubah menjadi kota bersih serta hijau dan telah mendapatkan piala Adipura dengan kriteria terbersih peringkat pertama untuk kota metropolitan. Bahkan, Palembang telah menambah catatan baru atas sebuah prestasi gemilang dengan memperoleh Piala Adipura tujuh kali secara berturutturut. Kondisi tersebut tentu saja mencengangkan banyak pihak, termasuk sebagian masyarakat Palembang sendiri yang masih kurang yakin dengan sejumlah penghargaan tersebut. Namun itulah kenyataannya, Kota Palembang kini semakin dikenal di kancah nasional dan internasional. Berbagai 
event nasional dan bahkan internasional telah dilaksanakan di kota ini.

Karena kota Palembang merupakan kota yang sangat cepat dalam menuntaskan masalah kebersihan, maka pada tahun 2008, Palembang dianugerahi tropi Asean Award untuk kategori Kota Bersih berwawasan lingkungan yang berkelanjutan (Asean Suitable Enviromentally City) oleh panitia Adipura tingkat Asean. Atas dasar keberhasilan tersebut, kepada 1.200 petugas kebersihan kota atau pasukan kuning yang bekerja tanpa kenal lelah, pemerintah kota telah memberikan apresiasi berupa kenaikan gaji serta kado umroh bagi beberapa petugas. Ini sebagai penghargaan atas pengabdian mereka serta diharapkan dapat memacu dan memicu mereka lebih semangat dalam menjaga kebersihan Kota Palembang. Selain itu, untuk menjadikan Palembang lebih rindang dan membuat Ruang Terbuka Hijau (RTH) menjadi lebih proporsional, Pemerintah Kota pun membagikan sekitar 5 ribu pohon tembesi ke 16 kecamatan di wilayah Kota Palembang. Dipilihnya pohon tembesi karena pohon ini dapat dikategorikan sebagai pohon yang sangat baik dalam mencegah pemanasan global . Ini dikarenakan pohon tembesi dapat mengikat secara efektif karbon dioksida dari udara. Berdasarkan penelitian untuk satu pohon tembesi yang memiliki usia 8 tahun, tinggi 10 meter mampu untuk menyerap 28 ton karbon dioksida per tahunnya. Jika 5 ribu pohon tersebut telah tumbuh besar di Palembang, bukan tidak mungkin ancaman pemanasan global dapat diminimalisir (http://satriawongjawa.wordpress.com/2010/08/30/ mensulap-palembang-dari-terjorok-menjaditerbersih-go-to-clean-green-and-blue-city/ diakses tanggal 25 Juni 2013).

Penelitian ini menggunakan metode penelitian kualitatif deskriptif dengan teknik pengumpulan data melalui observasi, studi dokumentasi (dokumen tertulis, arsip, catatan resmi, catatan atau tulisan pribadi, dan gambar atau foto) dan wawancara mendalam kepada informan terpilih. Ada 6 (enam) informan terpilih, 3 orang dari pejabat Dinas Kebersihan Kota Palembang, yang mengetahui dan memahami secara konsep dan praktis tentang tema yang diteliti, ditambah 3 (tiga) orang informan lagi, masing-masing 1 orang dari petugas kebersihan di lapangan (pasukan kuning), 1 (satu) orang anggota Tim Penilai Adipura di Jakarta, dan 1 (satu) orang anggota DPRD Kota Palembang yang membidangi komisi tentang kebersihan Kota Palembang.

Setelah dilakukan observasi, studi dokumentasi, dan wawancara mendalam, maka langkah berikutnya adalah melakukan triangulasi sumber data untuk menggali kebenaran informasi yang diperoleh. Melalui kajian akademik dan ilmiah, model implementasi kebijakan tersebut dikaji secara mendalam dan tidak menutup kemungkinan akan memunculkan dan melahirkan konsep model baru implementasi kebijakan dari sekian banyak model implementasi kebijakan yang telah ada sebelumnya, khususnya yang berkaitan dengan pengelolaan persampahan dan kebersihan kota.

Implementasi kebijakan, dalam pengertian yang luas, dipandang sebagai suatu tindakan dari proses kebijakan segera setelah undang-undang atau peraturan ditetapkan oleh lembaga yang berwenang, dan selanjutnya dilakukan oleh pemerintah, individu secara pribadi atau kelompok masyarakat untuk mencapai tujuan. Tindakan-tindakan yang dilakukan itu harus mampu mengaitkan antara tujuan yang dirumuskan dan realisasi atau hasil yang akan dan atau telah dilakukan, agar ada sinkronisasi. Grindle (1980:6) menghubungkan antara tujuan kebijakan terhadap realisasi dengan hasil kegiatan pemerintah, dengan menyatakan bahwa: In general, the task of implementation is to establish a link that allows the goals of public policies to be realized as outcomes of governmental activity. In involves, therefore, the creation of a "policy delivery system", in which specific means are designed and pursued in the expectation of arriving at particular ends. Mencermati pernyataan di atas, secara umum, implementasi adalah untuk membangun hubungan yang memungkinkan tujuan kebijakan publik dapat direalisasikan sebagai hasil dari kegiatan pemerintah.

Tindakan-tindakan yang cermat tersebut dalam suatu organisasi dilakukan oleh pejabat yang memiliki kewenangan atau otoritas sesuai mekanisme dan prosedur yang berlaku, menggunakan sarana dan prasarana, serta dilakukan secara bersamasama untuk mencapai tujuan. Dalam kaitan makna implementasi tersebut, Lester dan Stewart (2000: 104-105) mengemukakan bahwa; Implementasi bermakna pelaksanaan undang-undang di mana berbagai aktor, organisasi, prosedur, dan teknik bekerja bersama-sama untuk menjalankan kebijakan dalam upaya meraih tujuan-tujuan kebijakan atau program-program. Implementasi pada sisi lain merupakan fenomena yang kompleks yang mungkin dapat dipahami sebagai suatu proses, suatu keluaran (output) maupun sebagai suatu dampak (outcome).

Pengertian tersebut menunjukkan bahwa implementasi kebijakan adalah melaksanakan undang-undang dalam bentuk program kerja yang lebih operasional oleh aktor/implementor dalam organisasi yang terorganisasi dengan baik, dilakukan dengan prosedur dan teknik kerja yang jelas, serta dilakukan secara bersama-sama untuk mencapai tujuan kebijakan. Memang, kenyataan menunjukkan bahwa implementasi kebijakan merupakan hal yang kompleks, karena dalam pelaksaannya merupakan satu sistem yang tidak lepas dari sub-subsistem yang ada (input- proses - output) sampai dengan outcome atau dampak yang ditimbulkan.

Dampak yang ditimbulkan dari implementasi kebijakan merupakan sasaran utama, oleh karena itu konsensus atau kesepakatan-kesepakatan para 
pejabat bawahan (implementer) sangat berperan serta dalam hal ini. Di samping itu, konsensus tersebut menunjukkan bahwa motivasi dan tanggung jawab pelaksana kebijakan dalam membangun organisasi sebagai wadah menjalankan amanah mensejahterakan masyarakat semakin terwujud. Gross dan Berstein dalam Winarno (2007:153) mengemukakan faktor-faktor yang memengaruhi konsensus dalam rangka pencapaian tujuan, yaitu: pertama, peran serta dapat menimbulkan semangat staf yang tinggi dan semangat staf yang tinggi diperlukan bagi implementasi yang berhasil; kedua, peran serta menimbulkan komitmen yang besar dan tingkat komitmen yang tinggi diperlukan untuk memengaruhi perubahan; ketiga, peran serta menimbulkan kejelasan yang lebih besar tentang suatu pembaruan dan kejelasan diperlukan untuk implementasi; dan keempat, peran serta memudahkan implementasi yang berhasil; para pejabat bawahan akan cenderung menentang suatu pembaruan, jika prakarsa atas pelaksanaan kebijakan semata-mata berasal dari pejabat yang menjadi atasan mereka.

Dalam pandangan lain, implementasi kebijakan mutlak terdiri atas 3 (tiga) unsur utama yang saling berkaitan satu sama lain sebagai suatu sistem. Menurut Abdullah (1988: 11) ketiga unsur utama tersebut meliputi: "(1) unsur pelaksana (implementor); (2) adanya program yang akan dilaksanakan; (3) target groups". Pada tingkat pemerintahan, pihak yang terutama berkewajiban melaksanakan kebijakan publik adalah unit-unit administratif atau unit-unit birokrasi.

Birokrasi pemerintah sebagai pihak yang bertanggung jawab dalam implementasi kebijakan yang dalam posisinya secara hierarkial adalah para pejabat dalam struktur organisasi mempunyai kekuasaan personal. Kekuasaan personal dalam pandangan Winarno (2007: 159), dapat diukur dari: pertama, pejabat melakukan rekrutmen dan seleksi, penugasan, dan korelasi, kenaikan pangkat, dan akhirnya pemecatan. Kedua, pejabat dapat melakukan kontrol anggaran belanja pada unit-unit yang ada, memiliki kewenangan untuk menanggapi pencapaian kebijakan yang memuaskan atau tidak memuaskan, dan mempunyai kekuasaan untuk memengaruhi perilaku bawahan.

Bentuk yang dipertangungjawabkan pemerintah dalam implementasi kebijakan adalah program-program yang telah dibuat dan disepakati sebelumnya melalui keputusan-keputusan kebijakan publik. Dalam kaitan itu, Tachjan (2008: 31) menyatakan bahwa "pada hakekatnya implementasi kebijakan adalah implementasi program." Hal yang sama juga dikemukakan Grindle (1980: 6) bahwa Implementation is that set of activities directed toward putting a program into effect. Berbagai program yang bersifat operasional tersebut harus dipahami oleh implementor/pelaksana program mengenai aspek isinya, tujuan/sasaran dari program tersebut, pengalokasian anggaran dan ketepatan peruntukannya, metode dan prosedur kerja secara tepat, serta kejelasan standar yang menjadi pedoman dalam pelaksanaannya.

Beberapa ahli berbeda pandangan mengenai keberhasilan suatu implementasi kebijakan apabila diterapkan dalam dunia nyata. Menurut Edwards III (1980: 9), dalam mengkaji implementasi kebijakan, terlebih dahulu perlu diajukan pertanyaan-pertanyaan sebagai berikut: "What are the preconditions for successful policy implementation? What are the primary obstacles to successful policy implementation?"Maksudnya, apa prasyarat untuk keberhasilan implementasi kebijakan? Apa hambatan utama keberhasilan implementasi kebijakan? Edwards berusaha menjawab dua pertanyaan penting ini dengan menguraikan empat faktor atau variabel krusial dalam implementasi kebijakan. Faktor-faktor atau variabel-variabel tersebut adalah: communication, resources, dispositions or attitudes, and bureaucratic structure (Edwards III, 1980: 10). Bila ditampilkan dalam bentuk gambar bagaimana keterkaitan antara faktor-faktor yang saling mempengaruhi baik langsung maupun tidak langsung terhadap implementasi kebijakan, dapat ditampilkan sebagai berikut:

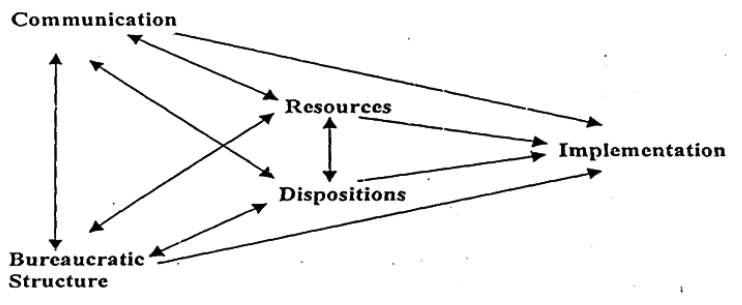

Gambar 1

Implementasi kebijakan menurut Edwards III (1980:148)

Selanjutnya, menurut Van Meter dan Van Horn (1975: 462-474), kinerja implementasi kebijakan pada dasarnya merupakan penilaian atas tingkat tercapainya standar dan sasaran tertentu yang telah ditetapkan dalam suatu kebijakan. Model yang mereka kembangkan lebih populer disebut sebagai A Model of the Policy Implementation Process. Model ini menjelaskan bahwa kinerja kebijakan dipengaruhi oleh beberapa variabel bebas yang saling berkaitan. Model yang ditawarkan meliputi enam variabel yang membentuk kaitan (linkage) antara kebijakan dan kinerja (performance). Model ini tidak hanya menentukan hubungan-hubungan antara variabelvariabel bebas dan variabel terikat mengenai kepentingan-kepentingan, tetapi juga menjelaskan hubungan-hubungan antar variabel-variabel bebas. Variabel-variabel tersebut, seperti diuraikan oleh Tachjan (2008: 39-40), meliputi: standar dan sasaran kebijakan, sumberdaya, karakteristik 


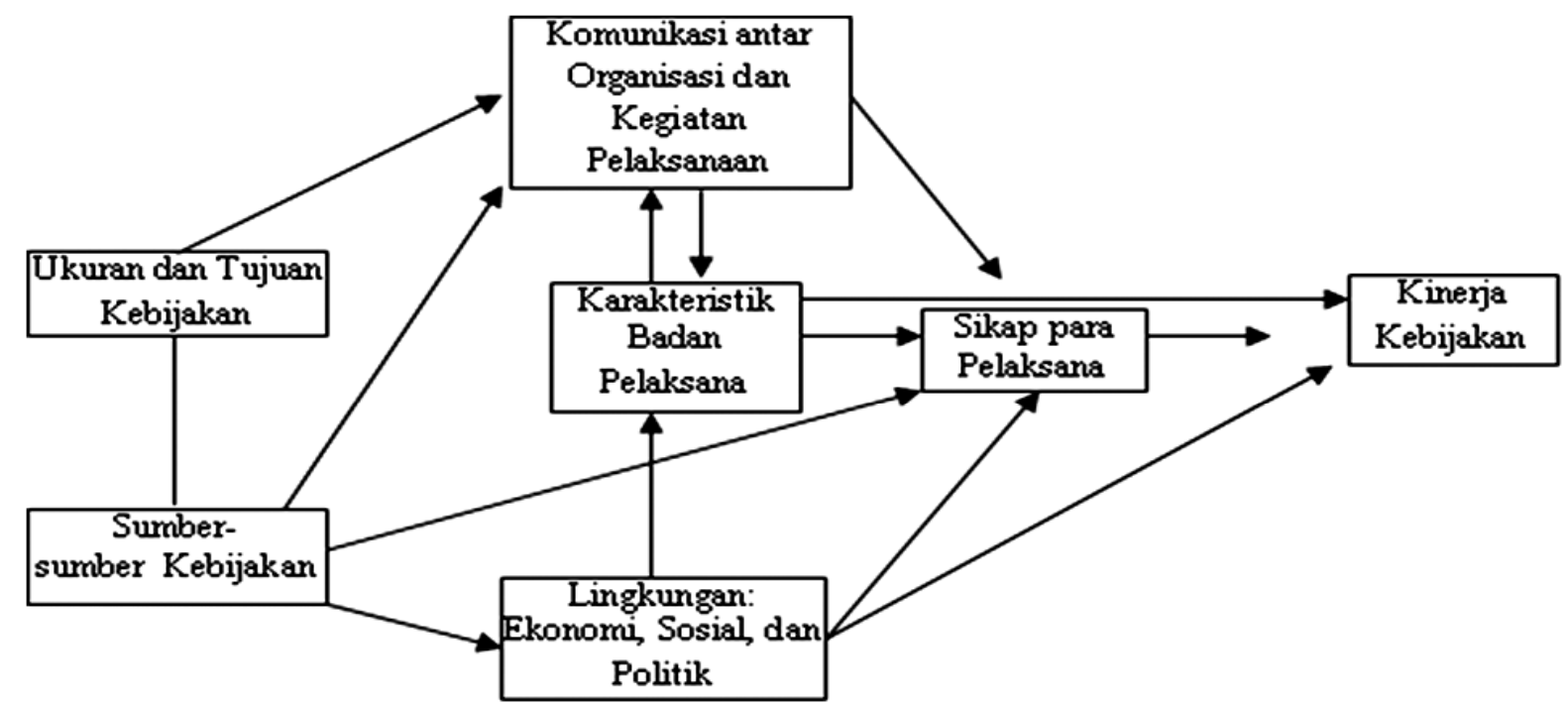

Gambar 2

Model Implementasi Kebijakan menurut Van Meter \& Van Horn (Winarno, 2007: 157)

organisasi pelaksana, komunikasi antarorganisasi terkait dengan kegiatan-kegiatan pelaksanaan, sikap para pelaksana, lingkungan sosial, ekonomi dan politik. Gambar model implementasi kebijakan dari Meter dan Horn adalah sebagaimana pada gambar 2.

Model implementasi kebijakan lainnya dikemukakan oleh Grindle (1980) yang lebih dikenal dengan pendekatan top-down. Pendekatan ini dikenal dengan Implementation is a Political and Administrative Process. Menurut Grindle variabel yang mempengaruhi implementasi kebijakan publik meliputi dua hal: pertama, dengan mempertanyakan apakah pelaksanaan kebijakan sesuai dengan yang ditentukan (design) dengan merujuk pada aksi kebijakannya. Kedua, apakah tujuan kebijakan tercapai. Tolok ukurnya dilihat dari dua faktor: (1) impak atau efek pada masyarakat secara individu dan kelompok; (2) tingkat perubahan yang terjadi serta penerimaan kelompok sasaran.

Oleh karena itu, Grindle (1980) mengomentari mengenai implementasi kebijakan sebagai berikut: Implementasi kebijakan sesungguhnya tidaklah sekadar bersangkut paut dengan mekanisme penjabaran keputusan-keputusan politik ke dalam prosedur-prosedur rutin lewat saluran-saluran birokrasi, melainkan lebih dari itu, ia menyangkut masalah konflik, keputusan, dan siapa yang memeroleh apa dari suatu kebijakan.

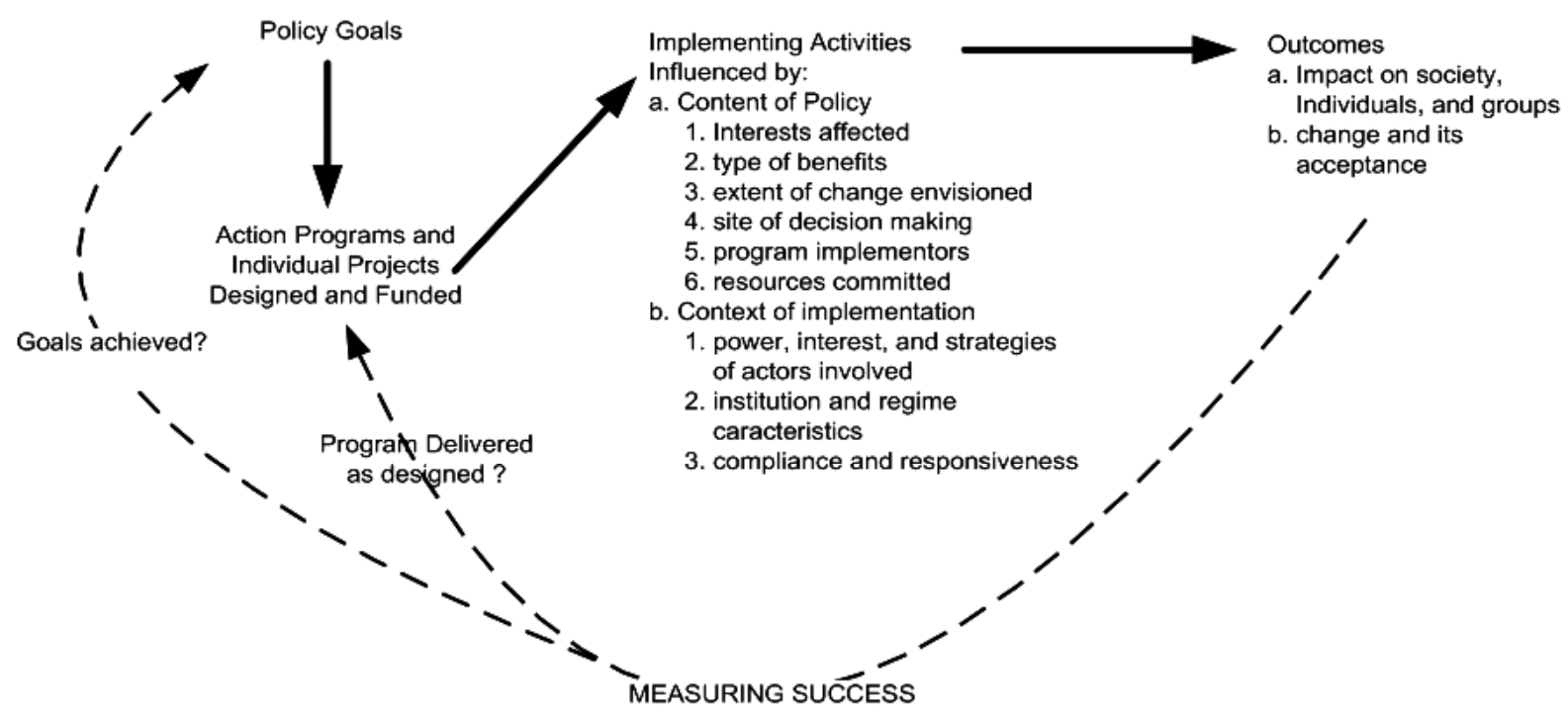

Gambar 3

Implementasi sebagai proses politik dan administrasi (Grindle, 1980: 11) 
Kerangka pemikiran Grindle (1980: 5) mengenai implementasi kebijakan, khususnya di negara berkembang, keberhasilannya ditentukan oleh derajat implementasi dari kebijakan tersebut, yaitu isi kebijakan dan konteks implementasi. Gambaran mengenai variabel yang saling memengaruhi dalam implementasi kebijakan tersebut digambarkan seperti pada gambar 3 .

Berbagai model implementasi kebijakan yang telah dijelaskan di atas, masing-masing memiliki kelebihannya sesuai dengan pandangan dari ahli yang melahirkan model tersebut dan konteks di mana kebijakan itu diimplementasikan. Tidak ada model tunggal yang sangat cocok atau sesuai dalam suatu kegiatan implementasi kebijakan, karena keberhasilan implementasi kebijakan sangat dipengaruhi oleh banyak indikator, dimensi, dan faktor, baik menyangkut implementasinya, pelaksana kebijakan, maupun lingkungan di mana kebijakan tersebut dilaksanakan.

\section{Model Implementasi Kebijakan Publik dalam Pengelolaan Persampahan dan Kebersihan Kota Palembang}

\section{Komunikasi}

Dinas Kebersihan Kota Palembang melaksanakan dua tugas pokok, yaitu (1) Melaksanakan kewenangan otonomi daerah di bidang kebersihan dan (2) Melaksanakan tugas khusus yang diberikan oleh pimpinan (Walikota, Wakil Walikota dan Sekda Kota Palembang). Sedangkan fungsi Dinas Kebersihan meliputi: (a) Membersihkan/ menyapu jalan, trotoar, pasar, terminal, dan fasilitas umum lainnya; (b) Mengangkut/membuang sampah dari TPS (tempat pembuangan sementara) ke TPA (tempat pembuangan akhir); (c) Melayani pengosongan septic tankdari lingkungan perumahan dan perkantoran, lalu membuangnya ke instalasi pembuangan limbah tinja (IPLT); (d) Pengelolaan, pemanfaaatan dan pemusnahan sampah di TPA; (e) Memelihara, merawat, menyimpan dan menyiapkan kendaraan angkutan sampah serta sarana kebersihan lainnya; dan (f) Memberikan penyuluhan kepada masyarakat mengenai kebersihan.

Agar tugas pokok dan fungsi tersebut dapat berjalan dengan baik, maka berdasarkan hasil wawancara dengan informan dari Dinas Kebersihan diperoleh informasi dan keterangan sebagai berikut: "bahwa keberhasilan pelaksanaan tugas pokok dan fungsi Dinas Kebersihan Kota Palembang serta pelaksanaan peraturan daerah tersebut, ditentukan oleh banyak hal, yang pertama tentu saja kegiatan sosialisasi dan komunikasi. Menurut Bastaman (2010:135), keberhasilan organisasi atau kinerja organisasi pada setiap leve/ atau jenis, termasuk organisasi pemerintah daerah akan sangat ditentukan oleh aktivitas komunikasinya atau komunikasi dalam organisasi.

Pada tahap awal, Walikota Palembang beserta jajarannya mengumpulkan para camat, lurah, RT, RW, dan satuan kerja perangkat daerah (SKPD) terkait, seperti Dinas Kesehatan, Dinas Informasi dan Komunikasi, dan Badan Lingkungan Hidup, lalu menyampaikan tentang keinginan agar Palembang menjadi kota bersih dan bila memungkinkan, mendapatkan piala Adipura. Pelaksanaan kebijakan tersebut dilakukan oleh Dinas Kebersihan sebagai penanggungjawab dan diperintahkan kepada pelaksana di lapangan dan masyarakat luas. Pelaksana di lapangan terdiri atas unsur Dinas Kebersihan, seluruh pegawai negeri sipil di lingkungan Pemerintah Kota Palembang, pasukan kuning, dan masyarakat umum."

Komunikasi yang dilakukan tentu saja yang berkaitan dengan pengelolaan persampahan dan kebersihan kota melalui berbagai media, mulai dari telepon, handphone, sms (short message service), televisi lokal (TVRI Stasiun Palembang, PaITV, atau Sriwijaya TV), koran, famplet, spanduk, baliho, dan lain-lain. Kemajuan teknologi komunikasi dan informasi dimanfaatkan secara optimal oleh pemerintah kota melalui Dinas Kebersihan, camat, lurah, RW, RT berserta jajarannya.

Hasil observasi di lapangan memang menunjukkan bahwa pesan-pesan tentang kebersihan terlihat di jalan-jalan protokol dan sudut-sudut kota Palembang, terutama di tempattempat keramaian seperti pasar-pasar tradisional, pusat-pusat perbelanjaan, pertokoan, dan tempattempat pembuangan sampah sementara. Pesanpesan tentang kebersihan kotapun kadangkala disampaikan melalui media seni pertunjukan "Dul Muluk" yang merupakan kesenian panggung asli Palembang. Komunikasi dengan memanfaatkan berbagai medium ini ternyata sangat efektif karena sesuai dengan budaya masyarakat Palembang, hal ini terlihat dari munculnya kesadaran sebagian besar masyarakat dalam rangka pengelolaan sampah dan kebersihan. Media lain yang juga dimanfaatkan adalah media cetak, seperti koran dan majalah/ buletin.

\section{Sumber daya}

Kelancaran saluran komunikasi tersebut juga sangat didukung oleh ketersediaan sumber daya yang ada, terutama berkaitan dengan sumberdaya manusia di lingkungan Pemerintah Kota Palembang, pada Dinas Kebersihan, Kantor Camat, Kelurahan beserta jajarannya. Sumberdaya aparatur tersebut telah mampu dan mau mengomunikasikan berbagai hal tentang kebijakan mengenai pengelolaan kebersihan dan persampahan, sehingga sebagian besar masyarakat memahami dan menaati kebijakan tersebut. Berdasarkan hasil wawancara, bahwa sumberdaya aparatur di lingkungan Dinas Kebersihan 
dilihat dari sisi jumlahnya sudah mencukupi, namun dilihat dari sisi kualitasnya relatif masih kurang, karena masih banyak aparat yang belum sempat mengikuti pendidikan dan latihan tentang pengelolaan persampahan dan kebersihan, padahal menurut Ariany \& Putera (2013: 40) pemerintah daerah harus memperhatikan kapasitas dan kualitas sumberdaya aparatur dengan melakukan pelatihanpelatihan untuk meningkatkan kinerja organisasi pelayanan publik bagi organisasi pemberi layanan publik di daerah.

Semua aparatur di lingkungan Pemerintah Kota Palembang boleh dikatakan telah terlebih dahulu mencontohkan kepada masyarakat tentang pentingnya lingkungan bersih. Semua kantor (kantor walikota, sekretariat daerah, sekretariat DPRD, dinas, badan, kecamatan, kelurahan, lingkungan sekolah TK, SD, SMP, SMA, SMK, dan perguruan tinggi) memiliki sarana dan prasarana untuk kebersihan dan memang dapat dijadikan contoh bagi masyarakat karena semuanya telah bersih.

Selanjutnya, untuk kebersihan lingkungan masyarakat umum, fasilitas umum, dan fasilitas sosial lainnya, Dinas Kebersihan Kota Palembang telah mengangkat 1000-an lebih pasukan kuning yang bekerja $3 x$ ship (selesai subuh, selesai duhur, dan selesai asar). Sumberdaya lain yang juga sangat menentukan dalam keberhasilan pengelolaan kebersihan di Kota Palembang adalah sumberdaya keuangan. Pemerintah Kota Palembang telah mengalokasikan anggaran yang cukup besar untuk kebersihan dan pengelolaan sampah dalam APBD. Sumberdaya berikutnya yang dimiliki oleh Dinas Kebersihan di antaranya fasilitas berupa armada angkutan yang dimiliki untuk menjaga kebersihan kota Palembang yang berjumlah 96 armada truk, dan 24 motor sampah. Untuk diketahui, dinas kebersihan kota Palembang rutin mengumpulkan sampah per hari dengan volume 600 ton. Sampah-sampah tersebut berasal dari rumah tangga, muara sungai, dan jalan raya.

\section{Sikap Implementor/Pelaksana}

Selanjutnya, diperoleh penjelasan pula bahwa implementasi kebijakan pengelolaan persampahan dan kebersihan ini sangat terkait juga dengan respons seluruh pelaksana di lapangan, mulai dari jajaran Dinas Kebersihan, seluruh aparatur, para camat, lurah beserta jajarannya, seluruh pasukan kuning (yang bertugas membersihkan/menyapu jalan, trotoar, pasar, terminal, dan fasilitas umum lainnya; mengangkut/membuang sampah dari TPS ke TPA; melayani pengosongan septic tank dari lingkungan perumahan dan perkantoran, lalu membuangnya ke Instalasi Pembuangan Limbah Tinja (IPLT); pengelolaan, pemanfaaatan dan pemusnahan sampah di TPA; serta memelihara, merawat, menyimpan, dan menyiapkan kendaraan angkutan sampah serta sarana kebersihan lainnya). Respons dan sikap pelaksana di lapangan ini tentu saja akan memberikan dampak yang luas bagi pengelolaan persampahan dan kebersihan di Kota Palembang.

Selama ini, sesuai dengan hasil wawancara dan penjelasan yang diperoleh dari Dinas Kebersihan dan pasukan kuning di lapangan bahwa respon dan sikap pelaksana sangat positif, baik pelaksana (pasukan kuning) maupun pelaksana dari masyarakat umum. Oleh karena itulah, maka apa pun bentuk produk kebijakan publik, mestinya pula memerhatikan kepentingan publik atau masyarakat, sebagaimana dikemukakan Tachjan (2008: 18) bahwa, "Kebijakan publik yang berkualitas tidaklah hanya berisi cetusan pikiran atau pendapat para administrator publik, tetapi harus berisi pula opini publik sebagai representasi dari kepentingan publik."

Komitmen para pelaksana untuk mensukseskan implementasi kebijakan dalam pengelolaan persampahan dan kebersihan sudah bagus, dibandingkan dengan respons dan sikap pelaksana di lapangan sekitar tujuh tahun yang lalu, memang luar biasa. Mereka, para pelaksana, terutama pegawai harian lepas ( $\mathrm{PHL}$ ) yang biasa dipanggil dengan "pasukan kuning", karena kostumnya berwarna kuning, yang berjumlah 1088 orang telah bekerja secara optimal, dari pagi hingga petang, mereka terus melakukan tugasnya. Pasukan kuning ini melakukan tiga fungsi; (1) sebagai penyapu rutin yang bertugas dari pukul 06.00 hingga pukul 09.00 pagi, kemudian dari pukul 14.00 hingga 16.00 sore; (2) penyapu keliling yang bertugas dari pukul 07.00 hingga 11.00 siang; dan (3) penyapu khusus yang bertugas di kawasan khusus (seputaran Benteng Kuto Besak, Pasar 16 Ilir, Taman Kambang Iwak, dan Taman Flyover Simpang Polda), mereka bertugas dari pagi, siang, dan malam. Para pasukan kuning ini mendapatkan upah sebesar Rp 1800000 (satu juta delapan ratus ribu rupiah) per bulan.

Respons dan sikap pelaksana yang positif tersebut tentu saja tidak terjadi dengan sendirinya dan secara tiba-tiba. Sikap pelaksana yang positif tersebut memang telah dibentuk sedemikian rupa dengan sistem rewarddan punishment. Berdasarkan informasi dari Dinas Kebersihan, para pegawai dan pasukan kuning yang telah menunjukkan kinerja yang bagus diberikan reward, seperti naik haji gratis, umroh gratis, pemberian piagam, pemberian tunjangan hari raya, pemberian beras, dan lain-lain. Sementara, yang kinerjanya rendah, yang malas, diberikan scorsing atau diganti dengan orang lain. Masyarakat juga memberikan respons dan sikap yang positif. Seringkali masyarakat memberikan informasi berkenaan dengan lingkungan yang kotor karena sampah kepada Dinas Kebersihan atau kepada UPTD di kecamatan setempat, baik secara lisan maupun melalui telepon atau SMS. Masyarakat juga telah menjadi mitra kerja Dinas Kebersihan, 
banyak masyarakat yang secara swadaya melalui RT atau RW menyediakan motor sampah dan gerobak sampah. Sampai sekarang tercatat tidak kurang dari 750 buah motor sampah dan 5000-an gerobak sampah di setiap kelurahan guna membantu pengelolaan persampahan dan kebersihan. Dinas Kebersihan menyebut mereka sebagai mitra kerja.

Berdasarkan hasil wawancara dengan Amelda (anggota Tim Penilai Adipura untuk Kota Palembang) diperoleh informasi sebagai berikut: "... bahwa Kota Palembang memang layak mendapatkan Piala Adipura karena dibandingkan dengan kota-kota metropolitan lain di Indonesia, Kota Palembang telah mampu mengimplementasikan kebijakan Undang-Undang Nomor 18 Tahun 2008 tentang Pengelolaan Sampah dan Peraturan Pemerintah Nomor 81 Tahun 2012 tentang Pengelolaan Sampah Rumah Tangga dan Sampah Sejenis Sampah Rumah Tangga. Penilaian indikator ini sangat menentukan, karena bobotnya sebesar $75 \%$ dari seluruh indikator yang ada. Indikator yang lain, seperti kualitas air dan udara juga memperoleh nilai yang lumayan (Wawancara, 19/8/2013)".

\section{Struktur Birokrasi}

Keberhasian implementasi kebijakan dalam pengelolaan persampahan dan kebersihan di Kota Palembang juga ditopang oleh birokrasi yang mudah dan melayani. Karena memang organisasi publik berorientasi kepada kepentingan dan pelayanan publik. Struktur organisasi pada Dinas Kebersihan Kota Palembang yang dalam istilah Kementerian Dalam Negeri adalah organisasi perangkat daerah yang "miskin struktur dan kaya fungsi." Berdasarkan Peraturan Daerah Kota Palembang No. 4 Tahun 2005 Bab IV Pasal 6, susunan organisasi Dinas Kebersihan Kota Palembang terdiri atas: (a) Kepala Dinas; (b) Bagian Tata Usaha; (c) Sub Dinas Operasional; (d) Sub Dinas Sarana Kebersihan; (e) Sub Dinas Pemakaman; (f) Sub Dinas Retribusi; (g) Kelompok Jabatan Fungsional; dan (h) UPTD. Pada tingkat kecamatan, kelurahan, RT dan RW serta wilayahwilayah pinggiran, UPTD yang banyak berperan dalam pengelolaan persampahan dan kebersihan di kawasan tersebut, sehingga birokrasi menjadi lebih gampang dan mudah.

Implementasi kebijakan tentang pengelolaan persampahan dan kebersihan yang bersifat kompleks menuntut adanya kerjasama banyak pihak. Ketika struktur birokrasi tidak kondusif terhadap implementasi suatu kebijakan, maka hal ini akan menyebabkan ketidakefektifan dan menghambat jalanya pelaksanaan kebijakan. Menurut Edwards III dalam Winarno (2007:150) terdapat dua karakteristik utama dari birokrasi yakni: Standard Operational Procedure(SOP) dan fragmentasi. SOP merupakan perkembangan dari tuntutan internal akan kepastian waktu, sumber daya serta kebutuhan penyeragaman dalam organisasi kerja yang kompleks dan luas. Ukuran dasar SOP atau prosedur kerja ini biasa digunakan untuk menanggulangi keadaan-keadaan umum diberbagai sektor publik. Dengan menggunakan SOP, para pelaksana dapat mengoptimalkan waktu yang tersedia dan dapat berfungsi untuk menyeragamkan tindakantindakan pejabat dalam organisasi yang kompleks dan tersebar luas, sehingga dapat menimbulkan fleksibilitas yang besar dan kesamaan yang besar dalam penerapan peraturan.

Sifat kedua dari struktur birokrasi yang berpengaruh dalam pelaksanaan kebijakan adalah fragmentasi. Edward III dalam Winarno (2007: 155) menjelaskan bahwa "fragmentasi merupakan penyebaran tanggung jawab suatu kebijakan kepada beberapa badan yang berbeda sehingga memerlukan koordinasi." Pada umumnya, semakin besar koordinasi yang diperlukan untuk melaksanakan kebijakan, semakin berkurang kemungkinan keberhasilan program atau kebijakan.

Fragmentasi mengakibatkan pandanganpandangan yang sempit dari banyak lembaga birokrasi. Hal ini akan menimbulkan konsekuensi pokok yang merugikan bagi keberhasilan implementasi kebijakan. Berikut hambatanhambatan yang terjadi dalam fregmentasi birokrasi berhubungan dengan implementasi kebijakan publik (Winarno, 2007:153-154): "Pertama, tidak ada otoritas yang kuat dalam implementasi kebijakan karena terpecahnya fungsi-fungsi tertentu ke dalam lembaga atau badan yang berbeda-beda. Di samping itu, masing-masing badan mempunyai yurisdiksi yang terbatas atas suatu bidang, maka tugas-tugas yang penting mungkin akan terlantarkan dalam berbagai agenda birokrasi yang menumpuk". "Kedua, pandangan yang sempit dari badan yang mungkin juga akan menghambat perubahan. Jika suatu badan mempunyai fleksibilitas yang rendah dalam misi-misinya, maka badan itu akan berusaha mempertahankan esensinya dan besar kemungkinan akan menentang kebijakan-kebijakan baru yang membutuhkan perubahan".

Sebelumnya, pada tahun 2005-2006, Palembang mendapat kategori kota terjorok di Indonesia. Kemudian dengan tekad dan keinginan serta komitmen yang kuat dari Walikota Palembang, Eddy Santana Putra, untuk mewujudkan Kota Palembang sebagai kota yang bersih, bukan sekadar motto "BARI" (Bersih, Aman, Rapi, dan Indah) namun realitasnya tidak demikian, maka berbagai daya dan upaya dilakukan oleh walikota beserta aparatur dan masyarakat Kota Palembang, dan akhirnya pada tahun 2006, kota Palembang mendapat predikat kota terbersih untuk kategori kota metropolitan dengan memperoleh Piala Adipura.

Predikat sebagai kota terbersih serta Piala Adipura ini pun terus disematkan kepada kota Palembang selama tujuh tahun berturut-turut. 
Keberhasilan Palembang mendapatkan predikat kota metropolitan terbersih dalam waktu relatif singkat tersebut telah membuat penasaran pemerintah kota lainnya $d$ Indonesia, sehingga mereka banyak yang melakukan studi banding ke Palembang, termasuk kalangan akademik untuk mengetahui model implementasi kebijakan yang bagaimana yang telah diadopsi Pemerintah Kota Palembang tersebut.

Berdasarkan hasil wawancara dengan Kepala Seksi Pengelolaan Kebersihan Dinas Kebersihan Kota Palembang diperoleh informasi bahwa: "semula pengelolaan persampahan dan kebersihan di Kota Palembang sebelumnya diatur dalam Peraturan Daerah Kota Palembang Nomor 12 Tahun 2006 tentang Pengelolaan dan Retribusi Persampahan dan Kebersihan, kemudian setelah lima tahun diberlakukan" sesuai dengan perkembangan dan dinamika yang ada, terutama berkaitan dengan besaran uang/dana operasional kebersihan yang sudah tidak sesuai lagi, serta dalam rangka menindaklanjuti Undang-Undang Nomor 18 Tahun 2008 tentang Pengelolaan Sampah, maka Pemerintah Kota Palembang mengeluarkan dan memberlakukan Peraturan Daerah Nomor 27 Tahun 2011 tentang Pengelolaan dan Retribusi Pelayanan Persampahan/ Kebersihan dan Penyediaan/Penyedotan Kakus. Keberhasilan dalam pengelolaan persampahan dan kebersihan di Kota Palembang tidak terlepas dari implementasi dua kebijakan tersebut (Wawancara, 27/6/2013).

\section{Komitmen Pimpinan}

Selanjutnya, keberhasilan kota Palembang mengelola persampahan dan kebersihan sehingga memperoleh Piala Adipura hingga tujuh kali berturutturut, di samping dipengaruhi dan ditentukan oleh empat faktor yang telah dikemukakan sebelumnya, yaitu faktor komunikasi/sosialisasi, sikap pelaksana, sumber daya, dan struktur birokrasi. Menurut Wakil Ketua Komisi III DPRD Kota Palembang, adanya "komitmen pimpinan" untuk mewujudkan kota Palembang menjadi kota yang bersih. Komitmen pimpinan tersebut terlihat dari upaya yang sungguhsungguh dari walikota, wakil walikota, sekretaris daerah, kepala dinas, dan jajaran pimpinan lainnya di lingkungan Pemerintah Kota Palembang. Menurutnya, tanpa ada komitmen yang teguh dan baik dari pimpinan ini, maka mustahil semua kebijakan tersebut dapat diimplementasikan. Komitmen ini betul-betul ditunjukkan oleh walikota dengan berbagai ide, pemikiran, gagasan, hingga pendanaan. Karena walikota sudah memiliki komitmen yang tinggi terhadap pengelolaan persampahan dan kebersihan ini, maka semua level pimpinan dalam jajaran pemerintahan mengikuti keinginan tersebut. Walikota Palembang, Eddy Santana Putra, seringkali langsung meninjau lokasi kota yang menjadi fokus yang dibersihkan, terutama kawasan-kawasan yang memang rentan dengan sampah (Wawancara, 9/8/2013).

Selanjutnya, sebagai bentuk komitmen dan tanggung jawab Walikota Palembang lainnya adalah sebanyak seribu orang lebih petugas kebersihan di Kota Palembang telah mendapat jaminan asuransi. Wali Kota, Eddy Santana Putra, mengatakan dalam menjalankan tugas mereka sangat rentan dengan kecelakaan kerja karena itu pemkot setempat telah mengasuransikan. "Jaminan asuransi kecelakaan itu menjadi salah satu bentuk tanggung jawab pemkot terhadap petugas kebersihan yang telah sangat berjasa," katanya. Menurut dia, pihaknya berupaya optimal memberikan berbagai fasilitas untuk kesejahteraan petugas kebersihan. Karena mereka menjadi ujung tombak dalam menjaga kebersihan dan keindahan kota, sehingga berhasil mempertahankan penghargaan tertinggi bidang kebersihan, Piala Adipura. Ia mengatakan, setiap tahun peningkatan pendapatan atau upah petugas kebersihan dilaksanakan secara rutin. "Upah petugas kebersihan naik sebesar Rp 5000 per hari yang diberlakukan sejak Januari lalu," katanya. Dia menjelaskan, kenaikan pendapatan petugas kebersihan itu sebagai salah satu bentuk komitmen pemkot dalam mendorong kesejahteraan mereka. Namun, memang tidak bisa dilakukan secara terus menerus dengan jumlah besar. Sementara, Kepala Dinas Kebersihan Kota Palembang, Kemas Abubakar menambahkan sebanyak 1085 orang petugas kebersihan mendapat tambahan upah Rp 5000 per hari. Dengan demikian, petugas kebersihan yang sebelumnya mendapat Rp 32500 per hari menjadi Rp37500 per hari.

Dikatakan, khusus untuk pengemudi truk sampah, naik menjadi Rp 65.000 dari sebelumnya, Rp60.000, per hari. Kenaikan upah petugas kebersihan tahun ini lebih besar darisebelumnya yang hanya Rp 2.500 per hari. (http://sumsel.antaranews. com/berita/273762/petugas-kebersihan-Palembangdijamin-asuransi. dakses tanggal 18 Juni 2013)

Beorientasi pada hasil penelitian yang telah dilakukan melalui wawancara mendalam dan observasi lapangan, maka dapat dikemukakan hasil kajian terhadap model implementasi kebijakan yang diadopsi/digunakan dalam pengelolaan kebersihan dan persampahan di Kota Palembang sebagai berikut: Pertama, model implementasi kebijakan yang dominan pada pengelolaan persampahan dan kebersihan di Kota Palembang lebih mengarah kepada model implementasi kebijakan yang dikemukakan oleh Edwards III dengan empat faktor implementasinya, yakni: komunikasi, sumber daya, sikap pelaksana, dan struktur birokrasi, adalah sebuah penegasan yang lebih menonjolkan pada eksistensi dari aparatur birokrasi pemerintahan, baik sebagai aktor maupun sebagai implementor kebijakan.

Kedua, model tersebut belum dalam 


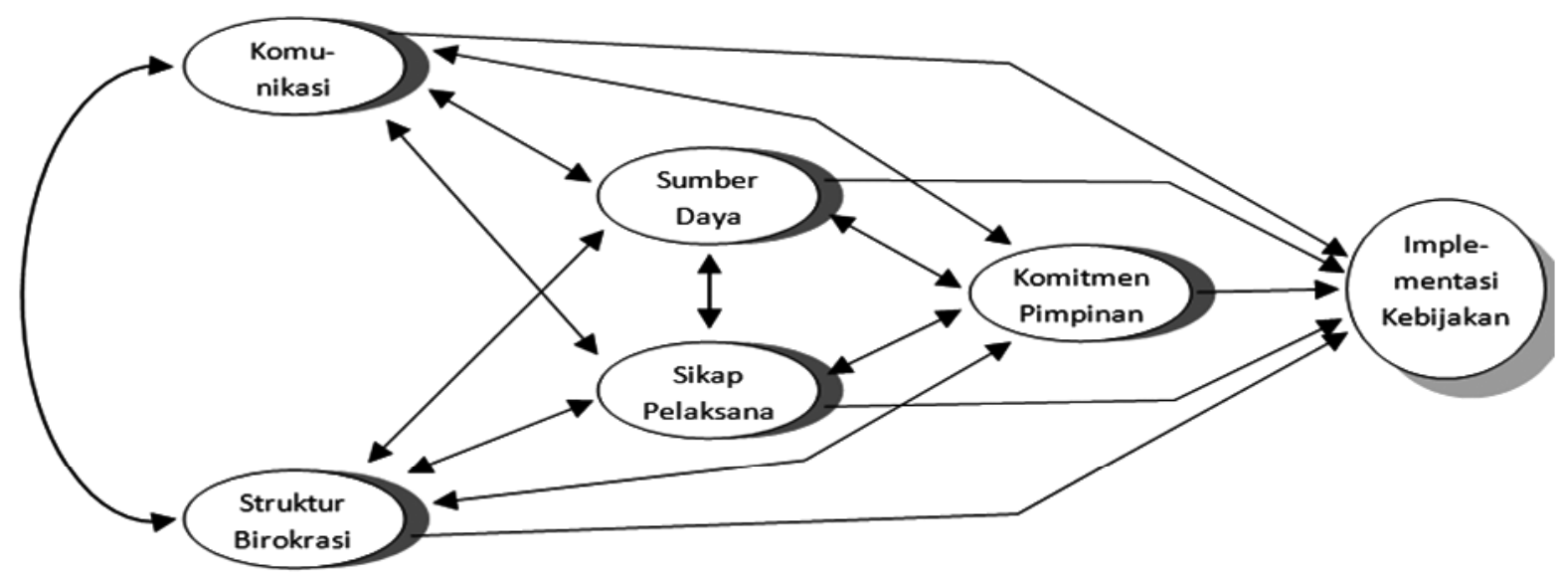

Gambar 4

Konsep Model Pengembangan Implementasi Kebijakan Publik dalam Pengelolaan Persampahan dan Kebersihan

realitasnya masih belum mempertimbangkan kondisi riil di lapangan. Kondisi riil menunjukkan bahwa walaupun empat faktor dari model teori implementasi kebijakan Edwards III diimplementasikan secara optimal, namun apabila tidak didukung oleh komitmen pimpinan (terutama pimpinan puncak), maka kebijakan tersebut sulit diimplementasikan. Hasil wawancara diperoleh keterangan bahwa pimpinan betul-betul memiliki komitmen untuk mewujudkan kota Palembang sebagai kota bersih. Hasilnya, sudah dapat dirasakan sekarang ini dan Piala Adipura selama tujuh tahun berturut-turut diperoleh Kota Palembang.

Oleh karena itulah, maka dapat dikemukakan di sini bahwa dalam proses implementasi kebijakan, selain memperhatikan dan menerapkan keempat faktor implementasi kebijakan, menurut Edwards III tersebut, juga perlu memperhatikan faktor lainnya, yakni komitmen pimpinan, terutama pimpinan puncak (walikota).

Dengan demikian, maka pengembangan teori model implementasi kebijakan, menurut Edwards III tersebut, dapat direkonstruksikan model pengembangannya sebagaimana pada gambar 4.

Khusus faktor kelima dari model pengembangan teori implementasi kebijakan publik, yakni komitmen pimpinan merupakan sesuatu yang melekat dalam diri seorang pemimpin. Faktor komitmen pimpinan tersebut dipandang penting diperhatikan khususnya dalam tataran implementasi kebijakan publik. Tidak sedikit produk kebijakan pemerintah ketika akan diimplementasikan, justru tidak berjalan secara optimal, hal ini dikarenakan tidak adanya komitmen pimpinan untuk melaksanakan kebijakan tersebut. Telah banyak kebijakan yang dibuat oleh pemerintah namun tidak berhasil diimplementasikan di lapangan karena tidak didukung oleh komitmen pimpinan. Keberhasilan pengelolaan kebersihan dan persampahan di Kota Palembang di samping karena faktor pelaksanaan komunikasi dan sosialisasi yang baik dan optimal terhadap kebijakan yang diambil, sumber daya yang memadai, sikap pelaksana (implementor) yang positif dan struktur birokrasi yang melayani, yang tidak kalah pentingnya adalah adanya "komitmen pimpinan" terhadap kebijakan yang diberlakukan, yaitu kebijakan tentang pengelolaan kebersihan dan persampahan.

\section{Simpulan dan Saran}

Berdasarkan hasil penelitian dan analisis/ pembahasan pada bab-bab sebelumnya, maka diperoleh simpulan sebagai berikut: (1) Model implementasi kebijakan dalam pengelolaan kebersihan dan persampahan di Kota Palembang lebih mengarah kepada model implementasi kebijakan dari Edwards III, yang meliputi empat faktor yang menentukan keberhasil implementasi kebijakan. Faktor-faktor tersebut adalah komunikasi, sikap pelaksana, sumber daya, dan struktur birokrasi; (2) Realitas menunjukkan bahwa faktor komunikasi, sikap pelaksana, sumber daya, dan struktur birokrasi yang dikemukakan oleh Edwards III, perlu ditambah dengan faktor lain, yaitu "komitmen pimpinan." Dalam penelitian ditemukan bahwa komitmen pimpinan (walikota) ternyata turut melengkapi keempat faktor tersebut; (3) Model implementasi kebijakan dari Edwards III yang terdiri atas empat faktor tersebut, setelah direkonstruksi ulang menjadi lima faktor, yaitu: komunikasi, sikap pelaksana, sumber daya, struktur birokrasi, dan komitmen pimpinan.

Berdasarkan simpulan tersebut, sudah seharusnya seorang pimpinan memiliki komitmen. Karena bila pimpinan memiliki komitmen yang jelas, maka akan diikuti oleh para bawahannya, dan tentu saja pada gilirannya semua apa yang menjadi kebijakannya akan direspons positif oleh bawahannya, termasuk masyarakatnya dan kelompok kepentingan yang lain. 


\section{Daftar Pustaka}

Abdullah. (1988). Perkembangan dan Penerapan Studi Implementasi (Action Research and Case Studies). Jakarta: Lembaga Administrasi Negara.

Ariany, Ria dan Putera, Roni Ekha. (2013). "Analisis Kinerja Organisasi Pemerintah dalam Memberikan Pelayanan Publik di Kota Pariaman." MIMBAR, Vol. 29, No. 1 (Juni, 2013): Hal. 33-40

Bastaman, Komir. (2010). "Pengaruh Iklim dan Kepuasan Komunikasi serta Komitmen terhadap Kinerja Pegawai." MIMBAR, Vol. XXVI, No. 2 (Desember 2010): Hal. 135-146.

Edwards III, George C. (1980). Implementing Public Policy. Washington, D.C: Congressional Quarterly Press.

Grindle, Merilee S. (1980). Politics and Policy Implementation in the Third World. New Jersey: Princeton University Press.

http://sumsel.antaranews.com/berita/273762/
petugas-kebersihan-Palembang-dijaminasuransi (dakses tanggal 18 Juni 2013). http://satriawongjawa.wordpress.com/2010/08/30/ (diakses tanggal 25 Juni 2013).

Lester, James P, dan Joseph Stewart, Jr. (2000). Public Policy; An Evolutionary Approach. Belmont, CA.: Wadsworth.

Meter, Donald S. Van dan Carl E. Van Horn. (1975). "The Policy Implementation Process: $A$ Conceptual Framework" in Administration and Suciety, Beverly Hills: Sage Publication.

Perda Kota Palembang No. 12 Tahun 2006 tentang Pengelolaan dan Retribusi Persampahan dan Kebersihan.

Tachjan. (2008). "Implementasi Kebijakan Publik." Bandung: Penerbit AIPI Bandung - Puslit KP2W Lemlit Unpad.

Winarno, Budi. (2007). Teori dan Proses Kebijakan Publik. Yogyakarta: Penerbit Media Pressindo. 